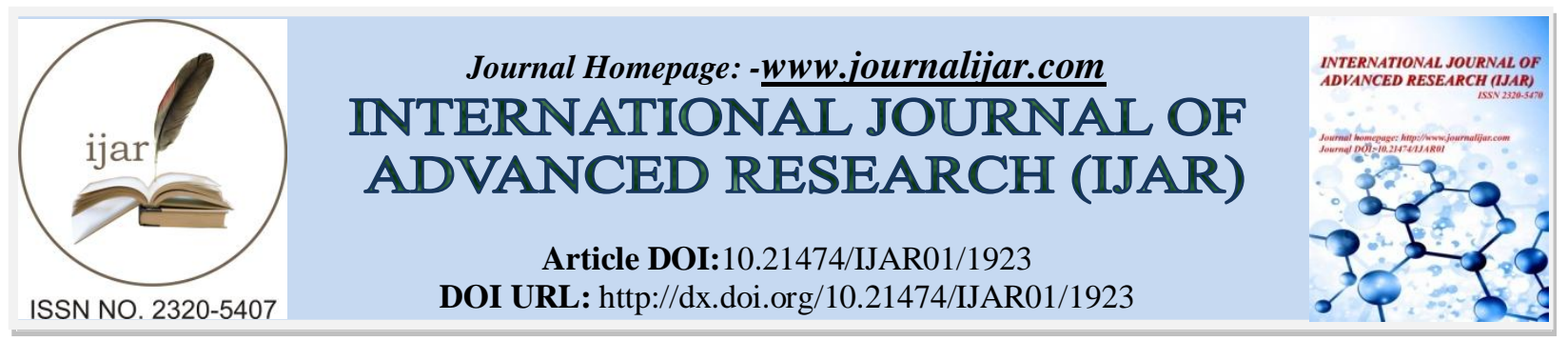

RESEARCH ARTICLE

\title{
THE VALIDITY OF SOME DOMINANT FISH OBTAINED FROM WADI EL-RAYAN LAKE FOR HUMAN CONSUMPTION.
}

*El-Sherif S. A., Ibrahim S. M. and Abd El-Gahfour S. A.

Fish Processing and Technology Lab, National Institute of Oceanography and Fisheries (NIOF), Egypt

\section{Manuscript Info}

Manuscript History

Received: 22 August 2016

Final Accepted: 16 September 2016

Published: October 2016

Key words:-

Wadi El-Rayan Lakes; fish; cooking

methods; quality criteria; pollutants

\section{Abstract}

This study aims to evaluate the validity of some dominant fish obtained from Wadi El-Rayan lakes for human consumption and also to investigate the effect of common cooking methods (grilling and frying) on quality criteria, organochlorine (OC) pesticide residues and heavy metals. Nile tilapia (Oreochromisniloticus) and mullet (Mugilcephalus) $\left(1^{\text {st }}\right.$ Lake) and red belly tilapia (Tilapia zillii) and mullet (Mugilcephalus) samples ( $2^{\text {nd }}$ Lake) during winter 2015 were obtained. Results showed that ranges of quality criteria of raw fish samples were $11.35-12.75 \mathrm{mg} / 100 \mathrm{~g}$ (total volatile basic nitrogen (TVBN), $0.48-0.80 \mathrm{mg} \mathrm{MAD} / \mathrm{kg}$ as thiobarbituric acid (TBA) value and $2.15-2.50 \times 10^{3} \mathrm{cfu} / \mathrm{g}$ total plate count (TPC). Organochlorine (OC) pesticide residues, average concentrations ranged between 0.017 $0.103 \mathrm{ppm}$ of $\Sigma$ DDT, $0.003-0.244 \mathrm{ppm}$ of $\Sigma$ Endosulfan, 0.014-0.126 ppm of $\Sigma$ Cyclodienes and $0.021-0.065 \mathrm{ppm}$ of $\Sigma \mathrm{HCH}(\beta, \gamma$ and $\delta)$ in the investigated fishes. Heavy metals levels in raw fish samples ranged 0.196-0.456 $\mathrm{Pb}$, UD-0.066 $\mathrm{Cd}, 0.052-0.226 \mathrm{Mn}, 0.018$ $0.057 \mathrm{Cu}$, and $0.086-0.538 \mathrm{Zn}(\mathrm{ppm}, \mathrm{ww})$. With regard to the effect of cooking methods, all values of quality criteria, most OC varied as affected by cooking methods applied, location and fish species. Frying of fish was more effective in reduction of OC components than grilling. However, grilling was reduced all heavy metals values in investigated fish samples, while levels of heavy metals were fluctuated in fried products. In conclusion, quality criteria and pollutants; OCP and heave metals in raw and cooked fish were lower the maximum permissible limits (MPLs) and therefore these fishes are validating for human consumption.

Copy Right, IJAR, 2016, All rights reserved.

\section{Introduction:-}

Wadi El-Rayan Protected Area (WRPA) encompasses the globally important Valley of the Whales World Heritage Site and the nationally important Rayan Lakes recreational area, among many other important natural, social and economic values. WRPA is located in the western part of the Fayoum Governorate, about $200 \mathrm{~km}$ southwest of Cairo. Also, the Rayan Lakes are a national recreational resource and a cornerstone of the Fayoum Governorate Ecotourism Plan (Palecznyet al., 2007). Both chemical and biological risks are foreseen to impair seafood safety in the future as a consequence of climate change; in particular, toxic metals, organic chemicals residues, algal toxins and pathogens of both humans and marine organisms. However, different species respond differently to such 
stresses. Public health authorities will face new challenges to guarantee seafood safety and to sustain consumers' confidence in eating seafood in a warmer world (Marques et al., 2010).

Pesticides constitute a major group of potential environmental hazards to man and have been routinely used in most countries of the world to control harmful pests. Some of these pesticides are the persistent organic pollutants (POPs) (Binelli and Provini, 2004). Kalyoncuet al. (2009) measured the levels of organochlorine pesticides in 18 fish species from Konya markets, Turkey. They found that DDT and its metabolites and HCH were the predominant contaminants in fish muscles. Detectable levels of $\mathrm{HCH}$, aldrin, and heptachlor were found in most samples. However, dieldrin, endrin, endosulfan, DDT, and DDD were not found in Salmotrutta. Yatawaraet al. (2010) measured the concentrations of OC pesticides in 13 species collected from different sites in the bays. The concentration of the sum of DDTs exceeded that the sum of HCHs in the samples. The estimated mean daily uptake of pesticides was below the level for minimal risk to the consumers. Abd-Allah (2013) found that the raw tilapia fish contained of OC pesticide residues (ppm) were $0.493 \beta$-BHC, 0.256 lindane, 0.714 heptachlor, 4.207 DDT complex, 0.124 chlordane, 3.412 total PCBs, 0.672 aldrin, 0.395 endrin, 1.608 dieldrin, and 2.023 toxaphene. However, the heptachlor epoxide and $\mathrm{HCH}$ components were not detected. Ghannamet al. (2014) found that chlorinated pesticides residues were ranged from 1.09-3.21, 0.48-1.22, $0.68-2.44 \mathrm{ng} / \mathrm{g}$ of total HGHs, DDTs and cyclodienes, respectively in fish samples collected from ElbahrElpharony drain. Nowadays, Sabiret al., (2016) monitored of water and sediment for pesticide residues and their bioaccumulation in fish of east Kolkata wetland. They found that average concentration of $\Sigma \mathrm{HCH}(\alpha, \beta, \gamma$ and $\delta)$ ranged between $1.23-8.9 \mu \mathrm{g} / \mathrm{kg}$ in Cyprinuscarpio, none in Oreochromismossambicus and only $\alpha-\mathrm{HCH}$ was recorded in Cirrhinusmrigata. Also, average concentration of $\Sigma$ DDT in three fish species ranged between $11.14-13.35 \mu \mathrm{g} / \mathrm{kg}$ and $\Sigma$ Endosulfan in fish flesh varied from 1.91$23.72 \mu \mathrm{g} / \mathrm{kg}$.

A heavy metal refers to any metallic chemical element that has a relatively high density and is toxic or poisonous at low concentrations (Irwandi and Farida, 2009). Storelliet al. (2007) determined four metals ( $\mathrm{Hg}, \mathrm{Cd}, \mathrm{Cu}$ and $\mathrm{Zn}$ ) in the muscle tissue of eels. Zn showed the highest concentrations (mean: $20.2 \mu \mathrm{g} / \mathrm{g}$ wet wt.), followed by $\mathrm{Cu}$ (mean: $0.58 \mu \mathrm{g} / \mathrm{g}$ wet wt.), $\mathrm{Hg}$ (mean: $0.18 \mu \mathrm{g} / \mathrm{g}$ wet wt.) and Cd (mean: $0.03 \mu \mathrm{g} / \mathrm{g}$ wet wt). None of the fish samples analyzed presented metal concentrations exceeding the proposed limits. Storelli (2008) analyzed edible marine species (fish, cephalopod molluscs, crustaceans) from the Adriatic Sea for content in heavy metals $(\mathrm{Hg}, \mathrm{Cd}$ and $\mathrm{Pb}$ ). Health risks to human via dietary intake of seafood were assessed by the target hazard quotients (THQs) and the toxic equivalent factors (TEFs). Abdel-Bakiet al. (2011) determined concentrations of some heavy metals $(\mathrm{Pb}, \mathrm{Cd}$, $\mathrm{Hg}, \mathrm{Cu}$ and $\mathrm{Cr}$ ) in water, sediment and tissues of tilapia fish collected from WadiHanifah during summer 2010. $\mathrm{Cu}$ had the highest accumulating level in fish whilst $\mathrm{Hg}$ had the lowest. Abd-Allah (2013) found that the raw Nile tilapia muscle contained 3.764, 5.091, 2.687, 0.259, 0.180, 1.506, 0.038, 0.225and $0.91 \mathrm{ppm}$ of $\mathrm{Fe}, \mathrm{Zn}, \mathrm{Pb}, \mathrm{Cr}, \mathrm{Zr}$, $\mathrm{Cu}, \mathrm{Cd}, \mathrm{Co}$ and $\mathrm{Hg}$, respectively (on wet weight). Fish is rarely eaten raw and usually cooked in different ways before consumption. Heating is one of the common methods in food processing. Heat is applied for food in different ways (Boiling, baking, roasting, frying and grilling) to enhance their flavor and taste; increase shelf life (GarciaArias et al., 2003). Also, cooking processes are known to reduce the burden of contaminants in fish. However, the mechanisms involved in the transfer and or degradation of contaminants during cooking process are not clear (Zabik and Zabik, 1999). The reduction in trace metals concentrations as affected by cooking methods may be due to the release of these metals with the loss of drip as free salts, possibly in association with soluble amino acids and uncoagulated proteins bounded with metals (Ersoyet al., 2006 and Ganbi, 2010). Abd-Allah (2013) found that the loss rates of OC ranged from 18.40 to $53.24 \%$ in fried, 12.8 to $40.15 \%$ in grilled products, respectively. On the other hand, the loss rates of the investigated heavy metals ranged from 18.40 to53.24\% in fried, 12.8 to $40.15 \%$ in grilled tilapia products.

Therefore, this study aims to evaluate the validity of some dominant fish; Nile tilapia (Oreochromisniloticus) and mullet (Mugilcephalus) from $1^{\text {st }}$ Lake, red belly tilapia (Tilapia zillii) and mullet (Mugilcephalus) samples from $2^{\text {nd }}$ Lake, during winter 2015 to study the quality criteria, organochlorine (OC) pesticide residues and heavy metals in raw fish and effect of common cooking methods (grilling and frying) on these parameters to evaluate the quality and safety of these fish species have been consumed from local people in Fayoum Governorate.

\section{Materials andMethod:-}

\section{Study area:-}

Wadi El-Rayan is a great depression $\left(703 \mathrm{~km}^{2}\right)$ situated in the Western Desert, $40 \mathrm{~km}$ southwest of El-Fayoum Province. Since 1973, the depression has been used as a water reservoir for agricultural drainage water exceeding 
the capacity of Lake Qarun. It holds two main lakes, at different elevations, connected by swampy channel. They lie between $30^{\circ} 20^{\prime}-30^{\circ} 25^{\prime} \mathrm{E}$ and $29^{\circ} 05^{\prime}-29^{\circ} 20^{\prime} \mathrm{N}$ (Fig. 1). The $1^{\text {st }}$ lake of Wadi El-Rayan covers an area of about $53 \mathrm{~km}^{2}$ at $10 \mathrm{~m}$ below the sea level and receives frequent effluent of wastewater from El-Wadi Drain (about 200 million cubic meters of agricultural drainage water are transported annually) (El-Shabrawy,2007). Surplus water from this lake floods to the second one via the shallow connecting channel. The $2^{\text {nd }}$ lake is larger than the first one $\left(110 \mathrm{~km}^{2}\right.$ at $18 \mathrm{~m}$ below the sea level) with maximum water depth recorded is $33 \mathrm{~m}$. It is changing all the time, where newly flooded areas are continuously added at the southwestern side of the lake. The inflow water to the second lake varied from $3.66 \times 10^{6} \mathrm{~m}^{3}$ in July to $17.68 \times 10^{6} \mathrm{~m}^{3}$ in March with a total annual of $127.2 \times 10^{6} \mathrm{~m}^{3} /$ year. The first Wadi El-Rayan lake is less saline (1.4-1.5 glL) than the second one (4.5-6.1 $\mathrm{glL}$ ), where the salinity increases southward (Mansour and Sidky, 2003). Nowadays, the varying degrees of salinity clear disparity between the two lakes, where the average of $1.95 \mathrm{~g} \backslash \mathrm{L}$ in the first lake and the second an average of $21.97 \mathrm{glL}$ (EEAA, 2016).

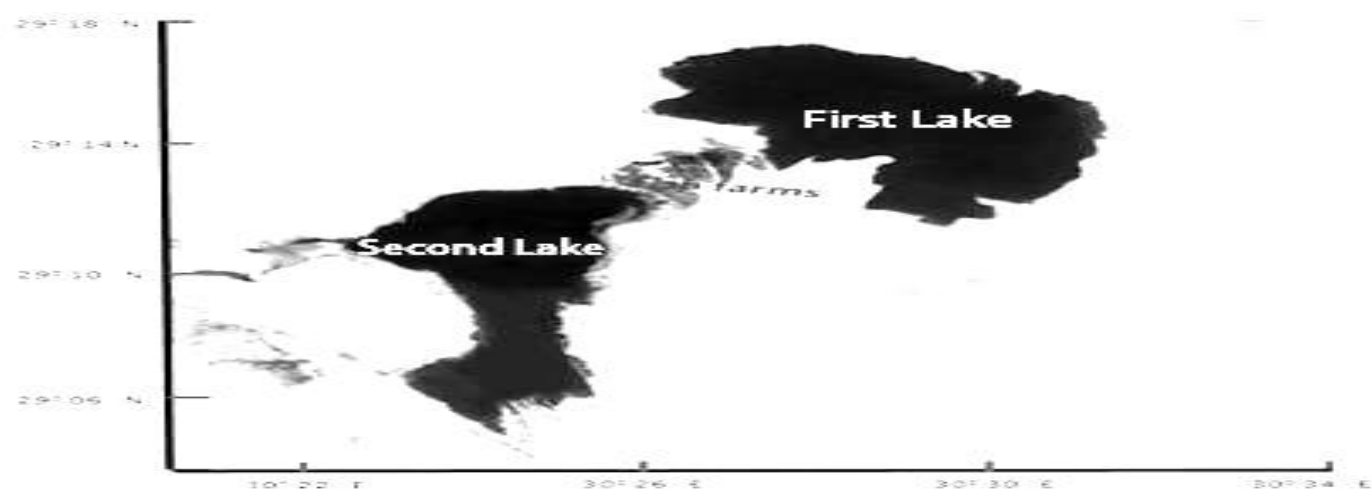

Fig. 1:-Wadi El-Rayan Lakes.

Fish samples:-

Four fish species were obtained fromWadi El-Rayan Lakes;Nile tilapia (Oreochromisniloticus) and mullet (Mugilcephalus) from $1^{\text {st }}$ Lake, red belly tilapia (Tilapia zillii) and mullet (Mugilcephalus) samples from $2^{\text {nd }}$ Lake, during winter 2015. Average of weight and length of investigated fish is shown in Table (1). They were kept in an ice chest and transported to the laboratory of Fish Processing and Technology, Shakshouk Station for Fish Research, National Institute of Oceanography and Fisheries, El-Fayoum Governorate, Egypt.The fish samples were beheaded, gutted, washed gently with tap water, then skinned by hand and filleted.

Table 1:- Length $(\mathrm{cm})$ and weight $(\mathrm{g})$ (mean $\pm \mathrm{SD}$ ) of dominant fish species from Wadi El-Rayan Lakes(1 \& 2) during winter, 2015.

Cooking methods:-

The fish samples from each species were divided into three groups, the first one is uncooked (raw) and the other two groups were cooked in the following methods: grilling and frying. The grilling was performed by rubbed fish

\begin{tabular}{|l|c|c|c|}
\hline Scientific name & English name & Length $(\mathrm{cm})$ & Weight $(\mathrm{g})$ \\
\hline \multicolumn{3}{|c|}{$1^{\text {st }}$ Lake } \\
\hline Oreochromisniloticus & Nile tilapia & $27.5 \pm 2$ & $452.5 \pm 50$ \\
\hline Mugilcephalus & mullet & $52.5 \pm 6$ & $1685 \pm 100$ \\
\hline \multicolumn{4}{|c|}{$2^{\text {nd }}$ Lake } \\
\hline Tilapia zillii & Red belly tilapia & $18.5 \pm 0.5$ & $112.5 \pm 20$ \\
\hline Mugilcephalus & mullet & $46.5 \pm 5$ & $1485 \pm 300$ \\
\hline
\end{tabular}

samples with bran and grilled using electrical grill machine at $180^{\circ} \mathrm{C}$ for $15 \mathrm{~min}$. In frying, the samples were breaded with wheat flour and deep oil-fried at $160^{\circ} \mathrm{C}$ for $10 \mathrm{~min}$ using sunflower oil. Raw and cooked fish samples were homogenized for analysis the quality criteria, organochlorine (OC) pesticide residues and heavy metals.

\section{Analytical Methods:-}

Total volatile basic nitrogen (TVB-N) was determined in $10 \mathrm{~g}$ of minced sample by micro-distillation method (Goulas and Kontominas, 2005) and the results were calculated as mg/100g sample. Thiobarbituric acid (TBA) value was calorimetrically determined (Castelliniet al., 2002) and the data were expressed as mg Malonaldehyde/kg sample. Total plate count (TPC); ten grams of sample was taken aseptically from different places and homogenized 
with $90 \mathrm{ml}$ of sterile saline solution. Standard plate count agar medium was used (Oxid, 1982). The results were expressed as cfu $\times 10^{3} / \mathrm{gm}$ sample. Organochlorine (OC) pesticides residues were determined according to TSQ 8000 GC/MS (Koc and Karakus, 2011). Organochlorine pesticides residues were expressed as (ppm, wet weight). Heavy metals; lead $(\mathrm{Pb})$, cadmium $(\mathrm{Cd})$, manganese $(\mathrm{Mn})$, copper $(\mathrm{Cu})$, and zinc $(\mathrm{Zn})$ were determined as described by Ghazaly (1988) using Atomic Absorption Spectrophotometer (Model Savant AA AAS with GF 5000 Graphite Furnace).Also, the results were expressed as (ppm, wet weight).

\section{Results and Discussion:- Quality criteria:-}

Table (2) shows quality criteria (ww) of raw and cooked fish obtained from Wadi El-Rayan Lakes during winter, 2015. TVB-N content was in range $11.35-12.60 \mathrm{mg} / 100 \mathrm{~g}$ sample in raw fish samples from $1^{\text {st }}$ Lake, while in $2^{\text {nd }}$ Lake, the corresponding value was $12.05-12.75 \mathrm{mg} / 100 \mathrm{~g}$ samples. TBA value was in range $0.48-0.75 \mathrm{mg} \mathrm{MAD} / \mathrm{kg}$ sample $1^{\text {st }}$ Lake while, it was $0.58-0.80 \mathrm{mg} \mathrm{MAD} / \mathrm{kg}$ sample in $2^{\text {nd }}$ Lake. In addition, TPC was in range 2.25$2.50 \times 10^{3} \mathrm{cfu} / \mathrm{g}$ of raw fish samples obtained lake 1 and $2.15 \times 10^{3} \mathrm{cfu} / \mathrm{g}$ sample in $2^{\text {nd }}$ Lake. A little high TVB-N and TBA values were found of fish samples in $2^{\text {nd }}$ Lake compared with that $1^{\text {st }}$ Lake, while TPC load was low. All these values were lower the maximum permissible limits as set by EOS (2005).

Table 2:- Quality criteria (w w) of raw and cooked fish from Wadi El-Rayan Lakes (1 \& 2) during winter, 2015.

\begin{tabular}{|c|c|c|c|c|c|c|c|c|c|c|c|c|c|}
\hline \multirow[t]{4}{*}{ Criterion } & \multirow[t]{4}{*}{ MPLs } & \multicolumn{12}{|c|}{ Quality criteria of raw and cooked fish obtained from Wadi El-Rayan Lakes; } \\
\hline & & \multicolumn{6}{|c|}{$1^{\text {st }}$ Lake } & \multicolumn{6}{|c|}{$2^{\text {nd }}$ Lake } \\
\hline & & \multicolumn{3}{|c|}{ Nile tilapia } & \multicolumn{3}{|c|}{ Mullet } & \multicolumn{3}{|c|}{ Red belly tilapia } & \multicolumn{3}{|c|}{ Mullet } \\
\hline & & Raw & Grilled & Fried & Raw & Grilled & Fried & Raw & Grilled & Fried & Raw & Grilled & Fried \\
\hline $\begin{array}{l}\text { TVN } \\
(\mathrm{mg} / 100 \mathrm{~g})\end{array}$ & 30 & 12.60 & 10.44 & 11.30 & 11.35 & 9.15 & 11.00 & 12.75 & 11.04 & 11.65 & 12.05 & 11.15 & 11.50 \\
\hline $\begin{array}{l}\text { TBA }(\mathrm{mg} \\
\mathrm{MAD} / \mathrm{kg})\end{array}$ & 4.6 & 0.75 & 0.42 & 0.50 & 0.48 & 0.38 & 0.40 & 0.80 & 0.47 & 0.55 & 0.58 & 0.43 & 0.48 \\
\hline $\begin{array}{l}\text { TPC } \\
(\text { count } \\
\left.\times 10^{3}\right)\end{array}$ & $10^{6}$ & 2.50 & 2.00 & 1.85 & 2.25 & 1.45 & 1.10 & 2.15 & 1.60 & 1.40 & 2.15 & 1.60 & 1.45 \\
\hline
\end{tabular}

TVB-N: Total volatile basic nitrogen (mg/100gm sample); TBA: Thiobarbituric acid (mg Malonaldehyde/kg sample); TBC: Total bacterial count (cfu $\times 10^{3} /$ gm sample);MPLs: Maximum permissible limits; EOS, 2005:Egyptian Organization for Standardization and Quality.Egyptian Standard, ES.

Concerning the effect of different cooking methods on quality criteria, cooking methods could be reduced in TVB-N and TBA values of cooked products in particular grilled products compared with fried samples whereas, frying was more effective in reduction of TPC than grilling. The loss of TVB-N due to the heating effect of cooking process may be related to the volatilization of the volatile nitrogen during frying or to its separation with dripping in grilling (El-Sherifet al., 2011). The lower of TBA values during cooking processes may be due to the formation of secondary products of lipid oxidation, which do not reaction with the TBA reagent or to the reaction (MA) with protein (Gokalpet al., 1983). TPC was sharply reduced in all cooked fish samples and influenced by cooking method; the highest reduction rate was observed in fried followed by grilled as compared with raw fish sample. This destruction occurred in TPC may be due to thermal processing during applied cooking methods. These changes in quality criteria are mainly depending on fish species, technological processes and cooking conditions used. All quality criteria of raw and cooked samples were less than the maximum permissible levels (MPLs); $30 \mathrm{mg}$ TVN/100g sample, $4.6 \mathrm{mg} \mathrm{MAD} / \mathrm{kg}$ and $<10^{6} \mathrm{cfu} / \mathrm{g}$ as set by (EOS, 2005). Therefore, all investigated fish species obtained from Wadi El-Rayan Lakes; $1^{\text {st }}$ Lake and $2^{\text {nd }}$ Lake were high quality and safety due to lower TVB-N, TBA and TPC values. These results are in agreement with reported byEl-Akeel (1983) and El-Sherifet al. (2011).

\section{Organochlorine $(\mathrm{OC})$ pesticides residues:-}

Organochlorine (OC) pesticide residues (ppm, ww) of raw and cooked fish obtained from Wadi El-Rayan Lakes during winter, 2015 are presented in Table (3). Sixteen components of OCP in raw and cooked fish products were determined; only 10 components (4, 4'-DDD, 4, 4'-DDE, endosulfan-I, endosulfan-II, endosulfan-sulfate, endrin, $\beta$ $\mathrm{HCH}, \gamma-\mathrm{HCH}$ and $\delta$-HCH)were detected and 6 others (4, 4'-DDT, heptachloro, heptachloroepoxid, endrin-aldehyde, 
Dieldrin and $\alpha-\mathrm{HCH}$ ) were not detectable. Ranges of detected components (ppm) were 0.017-0.028 4,4'-DDD, UD0.032 4,4'-DDE, 0.065-0.126 endosulfan-I, 0.188-0.244 endosulfan-II, 0.003-0.021 endosulfan-sulfate,UD-0.043 endrin, $0.021-0.052 \beta-\mathrm{HCH}, 0.037-0.067 \gamma-\mathrm{HCH}$ and $0.014-0.0 .043 \delta-\mathrm{HCH}$ in raw fish samples obtained from $1^{\text {st }}$ lake.

Table 3:-Organochlorine (OC) Pesticide residues (ppm, ww) of raw and cooked fish from Wadi El-Rayan Lakes (1 \& 2) during winter, 2015.

\begin{tabular}{|c|c|c|c|c|c|c|c|c|c|c|c|c|c|}
\hline \multirow[t]{4}{*}{ Component } & \multicolumn{12}{|c|}{$\begin{array}{l}\text { OC pesticide residues level (ppm, ww) of raw and cooked fish obtained from Wadi El- } \\
\text { Rayan Lakes; }\end{array}$} & \multirow{4}{*}{$\begin{array}{l}{ }_{* * *}^{\text {MPL }} \\
\text { (ppm } \\
\text { ) }\end{array}$} \\
\hline & \multicolumn{6}{|c|}{$\begin{array}{l}\text { Lake } 1 \\
\end{array}$} & \multicolumn{6}{|c|}{$\begin{array}{ll}\text { Lake 2 } \\
\end{array}$} & \\
\hline & \multicolumn{3}{|c|}{ Nile tilapia } & \multicolumn{3}{|c|}{ Mullet } & \multicolumn{3}{|c|}{ Red belly tilapia } & \multicolumn{3}{|c|}{ Mullet } & \\
\hline & $\begin{array}{c}\mathbf{R a} \\
\mathbf{w}\end{array}$ & $\begin{array}{c}\text { Grille } \\
\text { d }\end{array}$ & $\begin{array}{c}\text { Frie } \\
\text { d }\end{array}$ & $\begin{array}{c}\mathbf{R a} \\
\mathbf{w}\end{array}$ & $\begin{array}{c}\text { Grille } \\
\text { d }\end{array}$ & $\begin{array}{c}\text { Frie } \\
\text { d }\end{array}$ & $\begin{array}{c}\mathbf{R a} \\
\mathbf{w}\end{array}$ & $\begin{array}{c}\text { Grille } \\
\text { d }\end{array}$ & $\begin{array}{c}\text { Frie } \\
\text { d }\end{array}$ & $\begin{array}{c}\mathbf{R a} \\
\mathbf{w}\end{array}$ & $\begin{array}{c}\text { Grille } \\
\text { d }\end{array}$ & $\begin{array}{c}\text { Frie } \\
\text { d }\end{array}$ & \\
\hline 4,4'-DDD & $\begin{array}{c}0.01 \\
7\end{array}$ & 0.002 & UD & $\begin{array}{c}0.02 \\
8\end{array}$ & UD & $\begin{array}{c}0.00 \\
3\end{array}$ & $\begin{array}{c}0.01 \\
9\end{array}$ & 0.014 & $\begin{array}{c}0.01 \\
0\end{array}$ & $\begin{array}{c}0.04 \\
1\end{array}$ & 0.022 & UD & 0.5 \\
\hline 4,4'-DDE & $\begin{array}{c}0.03 \\
2\end{array}$ & 0.035 & $\begin{array}{c}0.05 \\
8\end{array}$ & UD & UD & $\begin{array}{c}0.08 \\
3\end{array}$ & $\begin{array}{c}0.10 \\
3\end{array}$ & 0.121 & $\begin{array}{c}0.16 \\
7\end{array}$ & $\begin{array}{c}0.06 \\
0\end{array}$ & UD & $\begin{array}{c}0.08 \\
6\end{array}$ & 0.5 \\
\hline 4,4'-DDT & $\begin{array}{c}\mathrm{UD} \\
*\end{array}$ & UD & UD & UD & UD & UD & UD & UD & UD & UD & UD & UD & - \\
\hline Endosulfan-I & $\begin{array}{c}0.12 \\
6\end{array}$ & 0.117 & $\begin{array}{c}0.11 \\
0\end{array}$ & $\begin{array}{c}0.06 \\
5\end{array}$ & 0.037 & $\begin{array}{c}0.02 \\
4\end{array}$ & $\begin{array}{c}0.16 \\
4\end{array}$ & 0.055 & $\begin{array}{c}0.05 \\
1\end{array}$ & $\begin{array}{c}0.12 \\
7\end{array}$ & 0.013 & $\begin{array}{c}0.00 \\
9\end{array}$ & 0.3 \\
\hline Endosulfan-II & $\begin{array}{c}0.24 \\
4\end{array}$ & 0.115 & $\begin{array}{c}0.04 \\
1\end{array}$ & $\begin{array}{c}0.18 \\
8\end{array}$ & 0.033 & UD & $\begin{array}{c}0.23 \\
7\end{array}$ & 0.211 & $\begin{array}{c}0.17 \\
7\end{array}$ & $\begin{array}{c}0.22 \\
0\end{array}$ & 0.103 & $\begin{array}{c}0.04 \\
6\end{array}$ & 0.3 \\
\hline $\begin{array}{l}\text { Endosulfan- } \\
\text { sulfate }\end{array}$ & $\begin{array}{c}0.02 \\
1\end{array}$ & 0.022 & $\begin{array}{c}0.04 \\
9\end{array}$ & $\begin{array}{c}0.00 \\
3 \\
\end{array}$ & 0.055 & $\begin{array}{c}0.00 \\
8\end{array}$ & UD & 0.018 & $\begin{array}{c}0.00 \\
9\end{array}$ & $\begin{array}{c}0.01 \\
1\end{array}$ & 0.001 & UD & 0.3 \\
\hline Heptachloro & UD & UD & UD & UD & UD & UD & UD & UD & UD & UD & UD & UD & - \\
\hline $\begin{array}{l}\text { Heptachloroep } \\
\text { oxid }\end{array}$ & UD & UD & UD & UD & UD & UD & UD & UD & UD & UD & UD & UD & - \\
\hline Endrin & $\begin{array}{c}0.04 \\
3\end{array}$ & 0.070 & $\begin{array}{c}0.04 \\
8\end{array}$ & UD & 0.060 & $\begin{array}{c}0.02 \\
3\end{array}$ & $\begin{array}{c}0.06 \\
5\end{array}$ & 0.143 & $\begin{array}{c}0.06 \\
7\end{array}$ & $\begin{array}{c}0.02 \\
1\end{array}$ & 0.026 & $\begin{array}{c}0.03 \\
1\end{array}$ & 0.3 \\
\hline $\begin{array}{l}\text { Endrin_aldehy } \\
\text { de }\end{array}$ & UD & UD & UD & UD & UD & UD & UD & UD & UD & UD & UD & UD & - \\
\hline Aldrin & UD & UD & UD & UD & UD & UD & UD & UD & UD & $\begin{array}{c}0.04 \\
0\end{array}$ & 0.021 & UD & - \\
\hline Dieldrin & UD & UD & UD & UD & UD & UD & UD & UD & UD & UD & UD & UD & - \\
\hline$\alpha-\mathrm{HCH}$ & UD & UD & UD & UD & UD & UD & UD & UD & UD & UD & UD & UD & - \\
\hline$\beta-\mathrm{HCH}$ & $\begin{array}{c}0.05 \\
2\end{array}$ & 0.038 & $\begin{array}{c}0.02 \\
7 \\
\end{array}$ & $\begin{array}{c}0.02 \\
1 \\
\end{array}$ & 0.030 & $\begin{array}{c}0.01 \\
9 \\
\end{array}$ & $\begin{array}{c}0.05 \\
4\end{array}$ & 0.038 & $\begin{array}{c}0.03 \\
1\end{array}$ & $\begin{array}{c}0.04 \\
5\end{array}$ & 0.041 & $\begin{array}{c}0.01 \\
5\end{array}$ & 0.3 \\
\hline$\gamma-\mathrm{HCH}$ & $\begin{array}{c}0.03 \\
7\end{array}$ & 0.018 & $\begin{array}{c}0.03 \\
4\end{array}$ & $\begin{array}{c}0.06 \\
7 \\
\end{array}$ & 0.055 & $\begin{array}{c}0.03 \\
2\end{array}$ & $\begin{array}{c}0.04 \\
1\end{array}$ & 0.032 & $\begin{array}{c}0.01 \\
3\end{array}$ & $\begin{array}{c}0.08 \\
0\end{array}$ & 0.034 & $\begin{array}{c}0.01 \\
2\end{array}$ & 0.3 \\
\hline 8-HCH & $\begin{array}{c}0.04 \\
3 \\
\end{array}$ & 0.026 & $\begin{array}{c}0.03 \\
1\end{array}$ & $\begin{array}{c}0.01 \\
4\end{array}$ & UD & $\begin{array}{c}0.01 \\
2\end{array}$ & $\begin{array}{c}0.06 \\
8\end{array}$ & 0.050 & $\begin{array}{c}0.03 \\
8\end{array}$ & $\begin{array}{c}0.12 \\
6\end{array}$ & 0.021 & $\begin{array}{c}0.05 \\
5\end{array}$ & 0.3 \\
\hline
\end{tabular}

UD*: undetectable

MPLs: Maximum permissible limits.

On the other side, raw fish samples from $2^{\text {nd }}$ Lake contained0.019-0.041, 0.060-0.103, 0.127- $0.164,0.200-0.237$, ud-0.011, 0.021-0.065, 0.045-0.054, 0.041-0.080 and 0.068-0.126, respectively, while aldrin component was detected only in raw and grilled mullet fish samples ( ${ }^{\text {nd }}$ Lake). It was noticed that the levels of pesticides detected in the raw fish were low, and did not exceed the maximum permitted levels EPA (2007) and FAO/WHO (2007), the higher levels of most detected components were found in fish samples from second Lake compared to that in first Lake. Similarly, Mansour and Sidky (2003) recorded some pesticide residues in the fish from Wadi El-Rayan Lakes and the second lake was more contaminated by trace metals and pesticides than the first. These traces of OC in fish flesh are due to agricultural and municipal discharges. Our results are in accordance with some those findings by Said and Hamed (2005); Storelli et al., (2007); Kalyoncuet al., (2009); Takahashi et al., (2010); Yatawaraet al., (2010); Ghannamet al., (2014) and lower than those found by Abd-Allah (2013) and Yehouenouet al., (2006) who reported that DDT, its metabolites and isomers were the most frequently identified pesticides in fish flesh. In addition to, Sabiret al., (2016) reported that though residues of certain pesticides were detected in fish, but their 
concentrations were much below the tolerance limit and the hazard index was very low. Concerning the effect of cooking methods, they could be reduced of 4,4'-DDD, endosulfan-I, endosulfan-II, endrin , aldrin, $\beta$ - $\mathrm{HCH}, \gamma-\mathrm{HCH}$ and $\delta$ - $\mathrm{HCH}$, while levels of $4,4^{\prime}-\mathrm{DDE}$ while,endosulfan-sulfate components were slightly increased, this is phenomenon may be due to decline in water content. In general, frying process of fish meat was more effective in reduction of some OC components than grilling. OCP in fish are depending on fish species, locations and cooking conditions. Our results are in agreement with Trotter et al. (1989) and Zabiket al. (1995); Witczak (2009) and AbdAllah (2013) who showed that reduction level in OCPs residues of processed fish tissues was depending upon the nature and solubility of pesticide itself, fish species, preparation treatments, the method of cooking or processing.

\section{Heavy metals levels:-}

Table (4) demonstrates heavy metals levels of raw and cooked fish from Wadi El-Rayan Lakes during winter, 2015. The levels of heavy metals in raw fish samples ranged from $0.196-0.415 \mathrm{pb}$, undetected (UD) - $0.058 \mathrm{Cd}, 0.062$ $0.116 \mathrm{Mn}, 0.026-0.051 \mathrm{Cu}, 0.086-0.221 \mathrm{Zn}$ and (ppm, fresh wet weight) in first lake. The corresponding levels ranged $0.299-0.456,0.048-0.066,0.052-0.226,0.018-0.057$ and $0.218-0.538 \mathrm{ppm}$, respectively in second lake samples. The concentrations of heavy metals in our study were slight lower than reported by Mohamed and Sabae (2015); who found that metal concentrations in Tilapia spp. from the first and second Wadi El-Rayan Lakes were 1.03, UD, 1.46, 3.20 and 36.58 (ppm, dry weight) of pb, $\mathrm{Cd}, \mathrm{Mn}, \mathrm{Cu}$, and $\mathrm{Zn}$ in $1^{\text {st }}$ Lake, while the corresponding levels were 5.6, UD, 7.57, 3.40 and $61.55 \mathrm{ppm}$, respectively in $2^{\text {nd }}$ Lake. Based on the obtained results, it was found that the levels of heavy metal in fish samples obtained from $2^{\text {nd }}$ Lake were higher concentration than that in $1^{\text {st }}$ Lake according to the increase in salt concentration, this agreed with those reported by Sayed and Abdel-Satar (2009). Also, the levels of $\mathrm{Pb}, \mathrm{Cd}, \mathrm{Mn}, \mathrm{Cu}$ and $\mathrm{Zn}$ in all investigated fish samples from Wadi El-Rayan Lakes were lower than the maximum permissible levels; 2.0, 1.0, 1.0, 30.0 and 100 ppm, respectively as set by WHO (1989). With regard to the effect of cooking methods, it was found that thermal process led to decrease or increase in investigated metals. $\mathrm{Pb}$ concentrations were decreased by both cooking methods; grilling or frynge in all types of fish investigated. The decrease in $\mathrm{Pb}$ concentrations in grilled fish samples is higher, when compared with the fried fish. The similar results were reported by (Diaconescuet al., 2012), who found that the $\mathrm{Pb}$ concentration in raw four fish species had values between $0.12-0,14 \mathrm{mg} / \mathrm{kg}$ dry weight decreased to $0.11 \mathrm{mg} / \mathrm{kg}$ in grilled samples and 0.12 $\mathrm{mg} / \mathrm{kg}$ in fried fish.

Table 4:- Heavy metals levels (ppm, ww) of raw and cooked fish obtained from Wadi El-Rayan Lakes (1 \& 2) during winter, 2015.

\begin{tabular}{|c|c|c|c|c|c|c|c|c|c|c|c|c|c|}
\hline \multirow[t]{4}{*}{ Item } & \multicolumn{12}{|c|}{ Heavy metals level (ppm, ww) of raw and cooked fish obtained from Wadi El-Rayan Lakes; } & \multirow{4}{*}{$\begin{array}{c}\text { MPL }_{*}^{*} \\
\text { (ppm } \\
\text { ) }\end{array}$} \\
\hline & \multicolumn{6}{|c|}{$\begin{array}{l}\text { Lake } 1 \\
\end{array}$} & \multicolumn{6}{|c|}{ Lake 2 } & \\
\hline & \multicolumn{3}{|c|}{ Nile tilapia } & \multicolumn{3}{|c|}{ Mullet } & \multicolumn{3}{|c|}{ Red belly tilapia } & \multicolumn{3}{|c|}{ Mullet } & \\
\hline & Raw & $\begin{array}{c}\text { Grille } \\
\text { d }\end{array}$ & $\begin{array}{c}\text { Frie } \\
\text { d }\end{array}$ & Raw & $\begin{array}{c}\text { Grille } \\
\text { d }\end{array}$ & $\begin{array}{c}\text { Frie } \\
\text { d }\end{array}$ & Raw & $\begin{array}{c}\text { Grille } \\
\text { d }\end{array}$ & $\begin{array}{c}\text { Frie } \\
\text { d }\end{array}$ & Raw & $\begin{array}{c}\text { Grille } \\
\text { d }\end{array}$ & $\begin{array}{c}\text { Frie } \\
\text { d }\end{array}$ & \\
\hline Lead $(\mathbf{P b})$ & $\begin{array}{c}0.41 \\
5\end{array}$ & 0.373 & $\begin{array}{c}0.38 \\
8\end{array}$ & $\begin{array}{c}0.19 \\
6\end{array}$ & 0.145 & $\begin{array}{c}0.18 \\
5\end{array}$ & $\begin{array}{c}0.45 \\
6\end{array}$ & 0.395 & $\begin{array}{c}0.41 \\
6\end{array}$ & $\begin{array}{c}0.29 \\
9\end{array}$ & 0.281 & $\begin{array}{c}0.31 \\
2\end{array}$ & 2 \\
\hline $\begin{array}{l}\text { Cadmium } \\
\text { (Cd) }\end{array}$ & $\begin{array}{c}0.05 \\
8 \\
\end{array}$ & 0.034 & $\begin{array}{c}0.05 \\
8 \\
\end{array}$ & UD* & 0.021 & $\begin{array}{c}0.05 \\
3 \\
\end{array}$ & $\begin{array}{c}0.06 \\
6 \\
\end{array}$ & 0.053 & $\begin{array}{l}0.06 \\
2 \\
\end{array}$ & $\begin{array}{c}0.04 \\
8 \\
\end{array}$ & 0.022 & $\begin{array}{c}0.04 \\
7 \\
\end{array}$ & 1 \\
\hline $\begin{array}{l}\text { Mangane } \\
\text { se (Mn) }\end{array}$ & $\begin{array}{c}0.11 \\
6 \\
\end{array}$ & 0.097 & $\begin{array}{c}0.11 \\
8 \\
\end{array}$ & $\begin{array}{c}0.06 \\
2\end{array}$ & 0.043 & $\begin{array}{c}0.09 \\
5\end{array}$ & $\begin{array}{c}0.22 \\
6 \\
\end{array}$ & 0.158 & $\begin{array}{c}0.29 \\
1\end{array}$ & $\begin{array}{c}0.05 \\
2\end{array}$ & 0.044 & $\begin{array}{c}0.09 \\
8\end{array}$ & 1 \\
\hline $\begin{array}{l}\text { Copper } \\
\text { (Cu) } \\
\end{array}$ & $\begin{array}{c}0.02 \\
6 \\
\end{array}$ & UD* & $\begin{array}{c}0.01 \\
8 \\
\end{array}$ & $\begin{array}{c}0.05 \\
1 \\
\end{array}$ & 0.016 & $\begin{array}{c}0.02 \\
1 \\
\end{array}$ & $\begin{array}{c}0.05 \\
7 \\
\end{array}$ & 0.017 & $\begin{array}{c}0.02 \\
1 \\
\end{array}$ & $\begin{array}{c}0.01 \\
8 \\
\end{array}$ & 0.003 & $\begin{array}{c}0.03 \\
3 \\
\end{array}$ & 30 \\
\hline Zinc (Zn) & $\begin{array}{c}0.22 \\
1\end{array}$ & 0.089 & $\begin{array}{c}0.26 \\
3 \\
\end{array}$ & $\begin{array}{c}0.08 \\
6\end{array}$ & 0.038 & $\begin{array}{c}0.11 \\
6\end{array}$ & $\begin{array}{c}0.53 \\
8\end{array}$ & 0.282 & $\begin{array}{c}0.58 \\
7\end{array}$ & $\begin{array}{c}0.21 \\
3\end{array}$ & 0.023 & $\begin{array}{c}0.34 \\
6 \\
\end{array}$ & 100 \\
\hline
\end{tabular}

UD*: undetectable MPLs*: Maximum permissible limits.

These findings also supported by Abdelhamidet al., (2016) that $\mathrm{Pb}$ in fresh Nile and farm tilapia fish were 0.205 and $0.152 \mathrm{ppm}$, wet weight, respectively decreased to 0.130 and $0.143 \mathrm{ppm}$ after frying. Cd concentrations were decreased in all types of fish investigated by two cooking methods, grilling and frying. This result is in accordance with the notes of Diaconescuet al. (2012). The Mn content of all investigated fish samples were increased by frying method but decreased in grilled fish samples. This result is in accordance with reported by Ersoy and Ozeren (2009), the Mn content of raw African catfish was $0.29 \mathrm{mg} / \mathrm{kg}$ increased in fried samples to $0.40 \mathrm{mg} / \mathrm{kg}$ and decreased to $0.25 \mathrm{mg} / \mathrm{kg}$ in grilled fish samples. The same trend of $\mathrm{Mn}$ was found in $\mathrm{Zn}$, The $\mathrm{Zn}$ content of fish samples was increased by frying but not for the grilled fish. Similarly,Ersoy and Ozeren (2009) reported that Zn content of raw 
African catfish was found to be $3.48 \mathrm{mg} / \mathrm{kg}$ increased to $5.99 \mathrm{mg} / \mathrm{kg}$ in fried fish while, decreased to $3.43 \mathrm{mg} / \mathrm{kg}$ in grilled fish. Changes occurred in heavy metals levels are in according to fish species, season, cooking methods and others as reported by Ersoyet al., (2006); Ganbi, (2010); Abd-Allah (2013) who reported that the reduction in trace metals concentrations as affected by cooking methods may be due to the release of these metals with the loss of drip as free salts, possibly in association with soluble amino acids and un-coagulated proteins bounded with metals, while, the increase in metals may be related to decrease in the moisture content that occur during cooking (Ersoyet $a l$, 2006).Therefore, grilling method was found higher appropriate for human consumption than frying for reducing the dangerous effect of heavy metals.

\section{Conclusion:-}

Based on these results, it could be summarized that all investigated fish species obtained from Wadi El-Rayan Lakes were high quality and safety due to lower TVB-N, TBA and TPC values. The burden OC pesticide residues and heavy metals were higher in fish samples in $2^{\text {nd }}$ Lake than those one $1^{\text {st }}$ Lake. The effect of cooking methods in reduction of pollutants; Frying caused loss in concentrations of most organochlorine pesticides examined compared with grilling and on contrast, grilling was high in reduction of heavy metals. However, OCP and heavy metals levels were well lower the safety permissible levels. Therefore, it can be concluded that common fish obtained from Wadi El-Rayan Lakes are validating for human consumption.

\section{References:-}

1. Abd-Allah, Shimaa, S. (2013). Studies on chemical and microbiological contaminants in some fish species and the influence of some cooking and processing methods on these contaminants. M. Sc. Thesis, Fac. of Agric. AL-Azher Univ., Egypt.

2. Abdel-Baki, A. S.; Dkhil, M. A. and Al-Quraishy, S. (2011). Bioaccumulation of some heavy metals in tilapia fish relevant to their concentration in water and sediment of WadiHanifah, Saudi Arabia. African Journal of Biotechnology, Vol. 10(13): pp. 2541-2547.

3. Abdelhamid, A. M.; Emara, H. M. and Pekhet, Mona A. M. (2016). Reducing lead content in tilapia and mugil during preparing and cooking of fish. Sustainable Aquaculture Magazine, May 2016.

4. Binelli, A. and Provini, A. (2004). Risk for human health of some POPs due to fish from Lake Iseo. Ecotoxicology and Environmental Safety, 58: 139-145

5. Castellini C.; Mugnai C. and Dal Bosco A. (2002). Effect of organic production system on broiler carcass and meat quality. Meat Sci. 60: 219-225.

6. Diaconescu, C.; Urdes, L.; Diaconescu, S. and Popa, D. (2012). Effects of cooking methods on the heavy metal concentrations in the fish meat originating from different areas of Danube River. Scientific Papers, Animal Science, Series D, vol. LV265-267.

7. EEAA (2016). Egyptian Environmental Affairs Agency. The environmental Monitoring Programme of the Egyptian lakes (WadiEl Rayan Lakes) Summary Report, February 2016. http://www.eeaa.gov.eg/en-us/topics/water/lakes.aspx.

8. EL-Akel, A. T. (1983). The effect of processing and storage on fish quality. M. Sc. Thesis. Fac. of Agric., Cairo Univ., A R E.

9. El-Shabrawy, G. M. (2007). Community structure and abundance of macrobenthos in Wadi El-Rayan Lakes (ElFayoum, Egypt). African Journal of Biological Science, 3(1):113-125.

10. El-Sherif, S. A.; Ibrahim S. M. and Abou-Taleb, M. (2011). Relationship between frozen pre-storage period of raw tilapia and mullet fish and quality criteria of its cooked products.Egyptian Journal of Aquatic Research, Vol. 37 (2):183-189.

11. EOS (2005). Egyptian Organization for Standardization and Quality. Egyptian Standard, ES.

12. EPA (2007). U.S. Environmental Protection Agency (March 27, 2007), Pesticides and food: What the pesticide residue limits are on food. EPA. Gov. Retrieved on September 15, 2008

13. Ersoy, B. and Ozeren, A. (2009). The effect of cooking methods on mineral and vitamin contents of African catfish. Food Chemistry 115:419-422

14. Ersoy, B.; Yanar, Y.; Küükgülmez, A. andÇelik, M. (2006). Effects of four cooking methods on the heavy metal concentrations of the sea bass fillets (DicentrarchuslabraxLinne, 1785). Food Chem., 99(4):748-751.

15. FAO/ WHO (1998). Food standards program of codex Alimentarius Commission about pesticide residues in food maximum residue limits. Vol. 2B, Rome.

16. FAO/WHO (2007). Safety evolution of certain food additives and contaminants. International program on chemical safety. WHO Geneva.

17. Ganbi, H. H. A. (2010). Heavy metals pollution level in marine Hammour fish and the effect of popular cooking methods and freezing process on these pollutants. World J. Dairy Food Sci., 5(2): 119-126. 
18. Garcia-Arias, M.T.; Pontes, E. A.; Garcia-Linares, M. C.; Garcia-Fernandaz, M. C. and Sanchez-Muniz, F. J. (2003b). Cooking-Freezing reheating (CFR) of sardine (Sardinapilchardus) fillets. Effects of different cooking and reheating procedures on the proximate and fatty-acid compositions.Food Chem. 83:349-356.

19. Ghannam, Hala E.; Talab, A. S.; Jahin, P. H. S. and Gaber S. E. (2014). Seasonal Variations in Physicochemical Parameters and Heavy Metals in Water of El-Bahr El-Pharaony Drain, El-Menoufia Governorate, Egypt. Research Journal of Environmental and Earth Sciences 6 (3): 174-181.

20. Ghazaly, K. S. (1988). The bioaccumulation of heavy metals in the tissue of the Egyptian edible marine animals. Part 1 Crustaceans. Bull. Nat. Inst. Oceanogr. Fish. A. R. E., 14:71-77.

21. Gokalp, H. A.; Ockerman, H. W.; Plimpton, R. F. and Harper, W. J. (1983). Fatty acids of neutral and phospholipids rancidity scores and TBA values as influenced by packaging and storage. J. Sci. Food Agric., 44:335.

22. Goulas A. E, Kontominas, M. G (2005). Effect of salting and smoking method on the keeping quality of Chub Mackerel (Scomberjaponicus): Biochemical and sensory attributes. Food Chem. 93:511.

23. Irwandi, J. and Farida, O. (2009).Mineral and heavy metal contents of marine fish in Langkawi island, Malaysia. International Food Research Journal, 16:105-112.

24. Kalyoncu, L.; Agca, I. and Aktumsek, A. (2009). Some organochlorine pesticide residues in fish species in Konya, Turkey Chemosphere 74:885-886.

25. Koc, F. and Karakus, E. (2011). Determination of organochlorinated pesticide residues by gas chromatography-mass spectrometry after elution in a florisil column. Kafkas Univ. Vet. Fak Dreg. 17 (1):65 -70.

26. Mansour, S. A. and Sidky, M. M. (2003). Ecotoxicological Studies. 6. The first comparative study between Lake Qarun and Wadi El-Rayan wetland (Egypt), with respect to contamination of their major components. Food Chem., 82:181-189.

27. Marques, A.; Nunes, L. M.; Moore, S. K. and Strom, M. S. (2010). Climate change and seafood safety: Human health implications. Food Research International 43:1766-1779.

28. Mohamed, Fatma, A. and Sabae, S. Z. (2015). Monitoring of pollution in Wadi El-Rayan lakes and its impact on fish. International Journal of Development, Vol.4, No. (1) (2015).

29. Oxoid (1982). Oxoid manual of culture media, ingredients and other laboratory services. $5^{\text {th }}$ Oxoid limited.

30. Paleczny, D.; Allam, K. and Talaat, M. (2007). The State of Wadi El-Rayan Protected Area and Valley of the Whales World Heritage Site, An Evaluation of Management Effectiveness. Egyptian-Italian Environmental Cooperation Programme, Nature Conservation Sector Capacity Building Project, Cairo. Nature Conservation Sector, Egyptian Environmental Affairs Agency, 2007, January 16, 2007.

31. Sabir, K.N.; Keya, S.; Samanta, S. and Sharma, A.P. (2016). Monitoring of water and sediment for pesticide residues and their bioaccumulation in fish of east Kolkata wetland. International Journal of environmental Sciences and Toxicology Research. Vol. 4 (6):96-102.

32. Said, T. O. and Hamed, M. A. (2005). Distribution of chlorinated pesticides in surface water and fish of El Temsah and Bitter lakes, Suez Canal. Egypt. J. of Aquatic Research, Vol., 31 (1): 202-212.

33. Sayed, M. F. and Abdel-Satar, Amaal, M. (2009). Chemical Assessment of Wadi El-Rayan Lakes, Egypt. AmericanEurasian J. Agric. \& Environ. Sci., 5 (1): 53-62

34. Storelli, M. M. (2008). Potential human health risks from metals ( $\mathrm{Hg}, \mathrm{Cd}$, and $\mathrm{Pb}$ ) and polychlorinated biphenyls (PCBs) via seafood consumption: Estimation of target hazard quotients (THQs) and toxic equivalents (TEQs). Food and Chemical Toxicology 46:2782-2788.

35. Storelli, M. M.; Barone, G.; Garofalo, R. and Marcotrigiano G. O. (2007). Metals and organochlorine compounds in eel (Anguilla anguilla)from the Lesina lagoon, Adriatic Sea (Italy) Food Chemistry 100: 1337-1340.

36. Trotter, W. J.; Corneliussen, P. E.; Laski R. R. and Vanelli, J. J. (1989). Levels of polychlorinated biphenyls and pesticides in blue fish before and after cooking. J. Assoc. Off. Anal. Chem., 72:501-503.

37. WHO (1989). Pesticide residues in food, FAO plant protection paper, 157-159.

38. Witczak, A. (2009). Effect of heat treatment on organochlorine pesticide residues in selected fish species. Pol. J. Food Nutr. Sci., Vol. 59 (3):231-235.

39. Yatawara, M.; Qi, S.; Owago, O. J.; Zhang, Y.; Yang, D.; Zhang, J. and Julia B. E. (2010). Organochlorine pesticide and heavy metal residues in some edible biota collected from Quanzhou Bay and Xinghua Bay, Southeast China. J. Environmental Sciences. 22(2):314-32.

40. Yehouenou, E.; Pazou, A.; Lalèyè P.; Boko, M.; Van Gestel, C. A. M.; Ahissou, H.; Akpona, S.; Van Hattum, B.; Swart, K. and Van Straalen, N. M. (2006). Contamination of fish by organochlorine pesticide residues in the Ouémé River catchment in the Republic of Bénin. Environment International, 32: 594-599.

41. Zabik, M. E. and Zabik, M. J. (1999). Polychlorinated biphenyls, Polybrominated biphenyls and dioxin reduction during processing / cooking food in impact of processing on food safety. Advances in experimental medicine and biology, Vol. 459 eds. L.S. Jakson, M.G.; Kinze, J.F. and Morgan. pp 213-231. New York. Plenum press.

42. Zabik, M. E.; Zabik, M.; Booren, A.; Nettles, M.; Song, J.; Welch, R. and Humphrey, H. (1995). Pesticide and total polychlorinated biphenyls in Chinook salmon and carp harvested from the Great Lakes: effects of skin-on and skinoff processing and selected cooking methods. J. Agric. Food Chem., 43:993-1001. 